


\title{
Sianida: Klasifikasi, Toksisitas, Degradasi, Analisis (Studi Pustaka)
}

\author{
M. M. Pitoia
}

aJurusan Kimia, FMIPA, Unsrat, Manado

\section{KATA K U N C I}

Sianida

Klasifikasi sianida

Toksisitas sianida

Degradasi Sianida

Analisis sianida

\section{K E YW O R D}

\section{Cyanide}

Cyanide classification

Cyanide toxicity

Cyanide degradation

Cyanide analysis

$\frac{\overline{\text { AVAILABLE ONLINE }}}{\text { Desember } 2014}$

A B S T R A K
Tulisan ini adalah studi pustaka mengenai sianida. Sianida adalah
kelompok senyawa yang mengandung gugus siano yang umumnya
diklasifikasikan sebagai sianida bebas, sianida sederhana dan kompleks
sianida. Ketoksikan sianida ditentukan oleh jenis dan konsentrasinya yang
umumnya dilihat dari kemampuannya melepaskan ion $\mathrm{CN}^{-}$yang berada
yang berada dalam kesetimbangan dengan $\mathrm{HCN}$ yang toksik. Sianida
dapat terdegradasi secara anorganik maupun biodegradasi. Beberapa
metode dapat digunakan untuk menganalisis sianida sebagai sianida
bebas (free cyanide), amenable cyanide, CN WAD, dan total sianida.
A B S T R A C T
This paper is a literature review of cyanide, which is a group of
compounds consist of cyano. Cyanide is classified as free cyanide, simple
inorganic cyanide and complex cyanide. Toxicity of cyanide is determined
by its type and concentration and usually related to its ability to release
CN- ion which is in equilibrium with HCN, a toxic species. Cyanide is able to
be degraded inorganically and biologically. Several methods have been
used to analyse cyanide as free cyanide, amenable cyanide, CN WAD and
total cyanide.

\section{Sianida dan klasifikasinya}

Sianida adalah kelompok senyawa yang mengandung gugus siano $(-\mathrm{C} \equiv \mathrm{N})$ yang terdapat dialam dalam bentuk-bentuk berbeda (Kjeldsen 1999, Luque-Almagro et al. 2011). Sianida di alam dapat diklasifikasikan sebagai sianida bebas, sianida sederhana, kompleks sianida dan senyawa turunan sianida (Smith and Mudder 1991).

Sianida bebas adalah penentu ketoksikan senyawa sianida yang dapat didefinisikan sebagai bentuk molekul ( $\mathrm{HCN})$ dan ion $\left(\mathrm{CN}^{-}\right)$dari sianida yang dibebaskan melalui proses pelarutan dan disosiasi senyawa sianida (Smith and Mudder 1991). Kedua spesies ini berada dalam kesetimbangan satu sama lain yang bergantung pada $\mathrm{pH}$ sehingga konsentrasi HCN dan $\mathrm{CN}^{-}$dipengaruhi oleh pH (Kyle 1988). Pada $\mathrm{pH}$ dibawah 7, keseluruhan sianida berbentuk HCN sedangkan pada $\mathrm{pH}$ diatas 10,5 , keseluruhan sianida berbentuk $\mathrm{CN}^{-}$(Kyle 1988). Reaksi antara ion sianida dan air ditunjukkan oleh dalam reaksi di bawah ini (Smith and Mudder 1991):

$$
\mathrm{CN}^{-}+\mathrm{HOH} \rightarrow \mathrm{HCN}+\mathrm{OH}^{-}
$$

Sianida sederhana dapat didefinisikan sebagai garam-garam anorganik sebagai hasil persenyawaan sianida dengan natrium, kalium, kalsium, dan magnesium (Kjeldsen 1999, Kyle 1988). Sianida sederhana dapat juga didefinisikan sebagai garam dari HCN yang terlarut dalam larutan menghasilkan kation alkali bebas dan anion sianida (Smith and Mudder 1991):

$$
\begin{aligned}
& \mathrm{NaCN} \leftrightarrow \mathrm{Na}^{+}+\mathrm{CN}^{-} \\
& \mathrm{Ca}(\mathrm{CN})_{2} \leftrightarrow \mathrm{Ca}^{2+}+2 \mathrm{CN}^{-}
\end{aligned}
$$

Bentuk sianida sederhana biasanya digunakan dalam leaching emas. Sianida sederhana dapat larut dalam air dan terionisasi secara cepat dan sempurna menghasilkan sianida bebas dan ion logam (Kyle 1988, Smith and Mudder 1991)

Kompleks sianida termasuk kompleks dengan logam kadmium, tembaga, nikel, perak, dan seng (Smith and Mudder 1991). Kompleks sianida ketika terlarut menghasilkan HCN dalam jumlah yang sedikit atau bahkan tidak sama sekali (Kyle 1988) tergantung pada stabilitas kompleks tersebut. Kestabilan kompleks sianida bervariasi dan

*Corresponding author: Jurusan Kimia FMIPA UNSRAT, Jl. Kampus Unsrat, Manado, Indonesia 95115; Email address: mariska.pitoi@unsrat.ac.id Published by FMIPA UNSRAT (2015) 
bergantung pada logam pusat (Smith and Mudder 1991). Kompleks lemah seperti kompleks dengan sianida dengan seng dan kadmium mudah terurai menjadi sianida bebas. Kompleks sedang lebih sulit terurai dibanding kompleks lemah dan meliputi kompleks sianida dengan tembaga, nikel, dan perak. Sedangkan kompleks kuat seperti kompleks sianida dengan emas, besi, dan kobalt cenderung sukar terurai menghasilkan sianida bebas.

Yang tergolong senyawa turunan sianida adalah $\mathrm{SCN}^{-}$(tiosianat), $\mathrm{CNO}^{-}$, dan $\mathrm{NH}_{3}$ (amonia) yang biasanya dihasilkan dari sianidasi, degradasi alami dan pengolahan limbah mengandung sianida (Smith and Mudder 1991).

\section{Ketoksikan Sianida}

Tingkat ketoksikan sianida ditentukan jenis, konsentrasi dan pengaruhnya terhadap organisme hidup (ATSDR 2006, Baxter and Cummings 2006, Smith and Mudder 1991). Ketoksikan sianida umumnya berhubungan dengan pembentukan kompleks dengan logam yang berperan sebagai kofaktor enzim. Sebagai contoh, sianida berikatan dengan enzim yang mengandung logam yang berperan dalam respirasi sehingga proses respirasi terganggu (Bishop 2000) Shifrin et al. didalam (Kjeldsen 1999). Enzim Fe(III) sitokrom-oksidase adalah salah satu contoh enzim dalam proses respirasi yang dihambat oleh sianida (Morper 1999).

Sianida dalam bentuk hidrogen sianida (HCN) dapat menyebabkan kematian yang sangat cepat jika dihirup dalam konsentrasi tertentu. ASTDR (2006) mencatat bahwa konsentrasi HCN yang fatal bagi manusia jika dihirup selama 10 menit adalah 546 ppm. Beberapa gangguan pada sistem pernapasan, jantung, sistem pencernaan dan sistem peredaran darah berhubungan dengan paparan terhadap sianida pada manusia dalam konsentrasi tertentu telah terdeteksi (ATSDR 2006).

Selain itu, sistem saraf juga menjadi sasaran utama sianida. Paparan HCN secara lama dalam konsentrasi tinggi dapat menstimulasi sistem saraf pusat yang kemudian diikuti oleh depresi, kejangkejang, lumpuh dan kematian (ATSDR 2006). HCN dapat terserap cepat ke dalam tubuh dan terbawa hingga ke dalam plasma.

Garam sianida dan larutan sianida memiliki tingkat ketoksikan yang lebih rendah dibandingkan HCN karena masuk ke tubuh hanya melalui mulut (Armour et al. 1987). Namun demikian, ketoksikannya dapat dianggap sebanding dengan HCN karena mudah menghasilkan HCN.

Kompleks sianida kurang toksik bila dibandingkan dengan sianida bebas. Sianida sederhana secara cepat dapat membebaskan sianida bebas dan menjadi sangat toksik, sedangkan kompleks sianida yang stabil tidak bersifat toksik selama tidak terurai menjadi sianida bebas. Ketoksikan kompleks sianida bervariasi tergantung kemampuannya untuk membebaskan sianida bebas (Baxter and Cummings 2006, Luque-Almagro et al. 2011).

Kompleks sianida yang kuat seperti kompleks sianida dengan besi dapat dikatakan tidak toksik, tetapi dengan kehadiran radiasi ultraviolet dapat terurai menghasilkan sianida bebas yang toksik.

\section{Degradasi Sianida}

Berikut ini adalah mekanisme degradasi alami sianida yang sering ditemukan dialam (Smith and Mudder 1991):

1. Kompleksasi. Ford (1964) yang dikutip oleh Smith dan Mudder (1991) melaporkan bahwa 28 logam dapat membentuk 72 kemungkinan kompleks dengan sianida. Kompleks sianida biasanya adalah zat antara dalam pembentukan senyawa yang lebih stabil yang mengeluarkan sianida bebas dari lingkungan tetapi kompleks ini bisa juga terdisosiasi dan kembali menghasilkan sianida bebas.

2. Pengendapan kompleks sianida. Ion-ion tertentu seperti besi, tembaga, nikel, mangan, timbal, seng, kadmium, timah, dan perak dapat bereaksi dengan kompleks sianida seperti $\left[\mathrm{Fe}(\mathrm{CN})_{6}\right]^{4-} \quad$ (ferosianida) dan $\left[\mathrm{Fe}(\mathrm{CN})_{6}\right]^{3-}$ (ferisianida) membentuk garam yang sukar larut (mengendap).

3. Adsorpsi. Adsorpsi adalah salah satu mekanisme atenuasi yang dapat mengurangi konsentrasi senyawa dari larutan di dalam tanah. Alesii dan Fuller (1976) yang dikutip Smith dan Mudder (1991) mengemukakan bahwa tanah dengan kapasitas penukar anion yang tinggi dapat mengadsorpsi sianida.

4. Oksidasi menjadi sianat $\left(\mathrm{CNO}^{-}\right)$. $\mathrm{HCN}$ dapat dioksidasi menjadi diubah menjadi $\mathrm{CNO}^{-}$yang kurang toksik bila dibandingkan dengan HCN.

5. Volatilisasi. Sianida dari larutan dapat lepas sebagai HCN yang adalah gas yang tidak berwarna. Gas HCN dapat terjadi karena hidrolisis $\mathrm{CN}^{-}$.

6. Pembentukan $\mathrm{SCN}^{-}$. Sianida dapat bereaksi dengan belerang membentuk tiosianat. Proses ini banyak terjadi pada saat leaching bijih emas yang banyak mengandung mineral sulfida.

7. Hidrolisis. Hidrolisis dapat mengelurkan HCN sebagai $\mathrm{NH}_{4} \mathrm{COOH}$ (ammonium format) atau $\mathrm{HCOOH}$ (asam format) menurut reaksi:

$$
\begin{aligned}
& \mathrm{HCN}+2 \mathrm{H}_{2} \mathrm{O} \rightarrow \mathrm{NH}_{4} \mathrm{COOH} \\
& \mathrm{HCN}+2 \mathrm{H}_{2} \mathrm{O} \rightarrow \mathrm{NH}_{3}+\mathrm{HCOOH}
\end{aligned}
$$

Degradasi sianida secara alami dapat terjadi tetapi berlangsung lambat melalui proses termasuk volatilisasi, oksidasi, dekomposisi cahaya dan biodegradasi (Kyle 1988). Sianida dalam konsentrasi yang kecil dapat didegradasi oleh mikroba tertentu menjadi gas nitrogen. Contoh mikroba yang dapat mendegradasi sianida adalah pseudomonas 
fluorescens NCIMB 11764 yang dapat menghidrolisis sianida menghasilkan asam format dan amonium (Luque-Almagro et al. 2011). Contoh lain adalah pseudomonas pseudoalcaligenes CECT5344 yang dapat mendegradasi sianida dengan menghasilkan amonium yang kemudian terinkoporasi dengan asam amino (Luque-Almagro et al. 2011)

\section{Analisis Sianida}

Dalam analisis sianida dikenal beberapa jenis analisis yang masing-masing mengukur kelompok sianida yang berbeda, yaitu :

a. CN Free atau sianida bebas yang meliputi spesies $\mathrm{CN}^{-}$dan $\mathrm{HCN}$ (Kyle 1988, Smith and Mudder 1991).

b. Amenable $\mathrm{CN}$ atau sianida yang mudah bereaksi dengan klorida, yang meliputi $\mathrm{CN}$ total kecuali kompleks sianida-besi (Kjeldsen 1999).

c. CN WAD (weak acid dissociable cyanide) yang meliputi CN bebas dan kompleks-kompleks sianida dengan tembaga, kadmium, nikel, seng, perak, dan logam-logam lain yang mudah terurai menjadi $\mathrm{CN}$ bebas dengan penambahan asam (Kjeldsen 1999).

d. CN total (sianida total) yang meliputi $\mathrm{CN}$ bebas, CN WAD, dan semua kompleks sianida kuat (memiliki tetapan disosiasi yang sangat rendah) seperti kompleks sianida dengan besi, emas, kobalt, dan platina (Kjeldsen 1999).

Ada berbagai metode yang dikenal dalam analisis sianida yang spesifik menganalis kelompok sianida tertentu. US EPA (United States of Environmental Protection Agency) dan ASTM (American Standard and Testing Materials) telah menetapkan metodemetode standard dalam analisis sianida. Smith dan Mudder (Smith and Mudder 1991) merangkum metode-metode tersebut sebagai:

a. Metode pengukuran $\mathrm{CN}$ total dengan destilasi. Sampel mengandung sianida ditambahkan asam kuat $(\mathrm{pH}<2)$ dan didestilasi reflux selama 1 jam sehingga sianida lepas sebagai $\mathrm{HCN}$ yang ditampung pada larutan $\mathrm{NaOH}$. Sianida yang tertampung kemudian diukur dengan titrimeti, kolorimetri atau elektroda ion selektif.

b. Metode pengukuran Amenable CN. Metode ini umum digunakan disaat metode analisis $\mathrm{CN}$ $W A D$ belum dikenal. Metode ini melibatkan pengukuran $\mathrm{CN}$ total sebelum dan sesudah klorinasi.

c. Metode pengukuran $\mathrm{CN}$ WAD dengan destilasi. Metode ini melibatkan destilasi refluks selama satu jam untuk menguapkan sianida dari sampel yang telah diatur pH-nya menjadi $\mathrm{pH} 3$ dengan larutan penyangga. Hasil HCN yang teruapkan diukur dengan titrimetri, kolorimetri atau dengan elektroda ion spesifik.

d. Metode penentuan $\mathrm{CN}$ WAD dengan asam pikrat. Metode ini melibatkan pembentukan senyawa berwarna dengan asam pikrat dengan kehadiran nikel yang diikuti dengan pemanasan menggunakan water bath selama 20 menit sebelum kemudian diukur dengan spektrofotometer vis.

e. Metode penentuan $\mathrm{CN}$ free dengan perak nitrat. Metode ini melibatkan titrasi sampel dengan larutan perak nitrat standard dengan menggunakan indikator dimetilaminobenzalrodamine.

f. Metode penentuan $\mathrm{CN}$ free dengan elektroda ion selektif. Metode ini melibatkan pengukuran langsung sampel menggunakan voltameter yang kemudian dibandingkan dengan elektroda referensi.

g. Metode ion kromatografi.

h. Metode penentuan sianida reaktif dengan USEPA test. Metode ini melibatkan penempatan sampel dalam massa yang sedikit kedalam asam sulfat dan melewatkan nitrogen secara terus-menerus kedalam sampel selama 30 menit. HCN kemudian dikumpulkan dari gas nitrogen di dalam wadah berisi $\mathrm{NaOH}$ dan kemudian diukur.

Selain metode yang dijelaskan diatas, ada juga beberapa metode yang digunakan untuk menganalisis sianida yang melibatkan penggunaan instrumen. Contohnya analisis sianida dengan spektrofotometer berdasarkan pembentukan warna dengan menggunakan asam pikrat (Adjei and Ohta 1999, Avais et al. 2011), fenolftalin (Cacace et al. 2007), reagen klorin-o-tolidin dan asam barbiturat-piridin (Gümüs et al. 2000), analisis sianida dengan mengukur radioaktivitas dari isotop sianida tertentu (Aronstein et al. 1994), dan analisis sianida dengan menggunakan ion kromatografi dengan detektor elektro kimia (Barclay et al. 1998).

Metode lain yang sekarang ini dikembangkan oleh Skalar adalah analisis CN total dan CN WAD secara otomatis menggunakan instrumen Skalar San+ system yang dikembangkan berdasarkan metode Kelada-01. Metode Kelada-01 (Kelada 1999) telah dipatenkan dan melibatkan penggunaan radiasi UV dan destilasi. Radiasi UV dengan frekuensi rendah digunakan untuk menguraikan kompleks sianida tanpa menguraikan tiosianat yang umumnya mengganggu dalam analisis sianida. Selanjutnya hasil penguraian tersebut didestilasi untuk mengukur sianida yang terbentuk.

\section{Daftar Pustaka}

Adjei, M. and Ohta, Y. (1999) Isolation and characterization of a cyanide-utilizing Burkholderia cepacia strain. World journal of microbiology \& biotechnology 15(6), 699-704.

Armour, M.A., Browne, L.M. and Weir, G.L. (1987) Hazardous Chemical: Information and disposal Guide. , University of Alberta, Edmonton.

Aronstein, B., Maka, A. and Srivastava, V. (1994) CHEMICAL AND BIOLOGICAL REMOVAL OF CYANIDES FROM AQUEOUS AND SOIL-CONTAINING 
SYSTEMS. Applied microbiology and biotechnology 41(6), 700-707.

ATSDR (2006) Toxicological Profile for Cyanide. Registry, A.f.T.S.a.D. (ed).

Avais, M., Khan, M.S., Khan, M.A., Ashraf, K., Nasir, A., Rabbani, M. and Hashmi, A.S. (2011) Modified picrate method for determination of cyanide in blood. Pakistan Journal of Pharmaceutical Sciences 24(2), 149-153.

Barclay, M., Hart, A., Knowles, C., Meeussen, J. and Tett, V. (1998) Biodegradation of metal cyanides by mixed and pure cultures of fungi. Enzyme and microbial technology 22(4), 223-231.

Baxter, J. and Cummings, S. (2006) The current and future applications of microorganism in the bioremediation of cyanide contamination. Antonie van Leeuwenhoek 90(1), 1-17.

Bishop, P.L. (2000) Pollution Prevention: Fundamentals and Practice, McGraw-Hill Co. Inc,, Singapore.

Cacace, D., Ashbaugh, H., Kaori, N., Bledsoe, S., Lancaster, S. and Chalk, S. (2007) Spectrophotometric determination of aqueous cyanide using a revised phenolphthalin method. Analitica Chemica Acta 589(2007), 137-141.
Gümüs, G., Demirata, B. and Apak, R. (2000) Simultaneous spectrophotometric determination of cyanide and thiocyanate after separation on a melamine-formaldehyde resin. Talanta 53(2000), 305-315.

Kelada, N.P. (1999) Irradiation-Distillation apparatus and method for measuring cyanide species., United States

Kjeldsen, P. (1999) Behaviour of cyanides in soil and groundwater: A review. Water, air and soil pollution 115(1-4), 279-307.

Kyle, J. (1988) The extraction and recovery of gold, WASM Metallurgy Department.

Luque-Almagro, V.M., Blasco, R., Martinez-Luque, M., Moreno-Vivian, C., Castillo, F. and Roldan, M.D. (2011) Bacterial cyanide degradation is under review: Pseudomonas pseudoalcaligenes CECT5344, a case of an alkaliphilic cyanotroph. Biochemical Society Transactions 39(1), 269-274.

Morper, M.R. (1999) Combination Therapy Tackles Wastewater Toxins Chemical Engineering 106(8), 66-70.

Smith, A. and Mudder, T. (1991) The Chemistry and Treatment of Cyanidation Waste, Mining Journal Books Ltd., London. 
